九州大学学術情報リポジトリ

Kyushu University Institutional Repository

\title{
Cell Wall Contents and Estimation of Genetic Parameters for Polysora Rust Resistance in Tropical Maize (Zea mays L.)
}

$\mathrm{Ji}$, Hee Chung

Grassland \& Forages Research Center, National Institute of Animal Science, Rural Development Administration

Yamakawa, Takeo

Laboratory of Plant Nutrition, Division of Molecular Biosciences, Department of Biosciences \& Biotechnology, Faculty of Agriculture, Kyushu University

https://doi.org/10.5109/20314

出版情報：九州大学大学院農学研究院紀要. 56 (2)，pp. 231-236，2011-09. Faculty of Agriculture， Kyushu University

バージョン：

権利関係: 


\title{
Cell Wall Contents and Estimation of Genetic Parameters for Polysora Rust Resistance in Tropical Maize (Zea mays L.)
}

\section{Hee Chung $\mathrm{JI}^{1}$ and Takeo YAMAKAWA*}

\author{
Laboratory of Plant Nutrition, Department of Bioscience \& Biotechnology, \\ Faculty of Agriculture Kyushu University, Faculty of Agriculture, \\ Kyushu University, 6-10-1 Hakozaki, Fukuoka 812-8581, Japan. \\ (Received April 12, 2011 and accepted May 9, 2011)
}

\begin{abstract}
Polysora rust (Puccinia polysora Underwood) of corn (Zea mays L.), known as southern rust, has enormous destructive potential on susceptible hosts. It occurs in the tropics and in warm temperate regions, and is especially severe in Hawaii's wet winter season. No temperate sweet corn hybrids can be grown commercially without fungicides in these months, but tropically adapted hybrids have an intermediate level of resistance that minimizes yield losses to this disease. Monogenic sources of resistance are ineffective in Hawaii, as they are throughout the tropics. Genetic parameters for general or horizontal rust resistance were estimated by evaluating six generations from crosses of the tropical sweet corn inbred, Hi38-71 (resistant), and a susceptible inbred, G24. Empirical scores ranging from 1 (highly resistant) to 9 (highly susceptible) were applied under uniform field epiphytotics of the rust. A simple three-parameter model (m, $[a] \&[d])$ did not fully explain those data. However, a digenic model that the incorporated epistasis adequately explained the variation in resistance. Epistatic interactions $[a a]$ and $[d d]$ were highly significant, while the $[a d]$ interaction was not. Heritability values were $68 \%$ for broad-sense and $53 \%$ for narrowsense, and were accompanied by estimates of about two controlling loci. The high significance of non-additive and epistatic effects makes clear that the breeding for rust resistance should be based on selection of both parents. Additional data were taken on Set M of recombinant inbreds (RILs), based on the cross of Hi38c1 and Ia453sh2 (susceptible). Previously reported, the parents averaged 3.1 (Hi38c1) and 5.3 (Ia453sh2), while the 55 RILs averaged 4.5 with skew showing high resistance. Under a second more severe epiphytotic, only 8 of the 52 tested RILs were comparable in resistance to the Hawaii parent. Data from the GMA (Generation Mean Analysis) and RIL studies, both of which were based on the moderately resistant Hi38, are similar in confirming that two to three loci are required to provide adequate field resistance for sweet corn growers. Crude protein of Hi 27 was higher as $10.43 \%$ than that of Hi38-71 but acid detergent fiber and neutral detergent fiber of Hi27 were lower as $34.70 \%$ and $65 \%$ than those of Hi38-71 in the cell wall contents. In parallel studies in Hawaii it is clear that tropical field corn hybrids must have much higher levels of resistance, and these resistance alleles appear to be available only among tropical inbreds.
\end{abstract}

\section{INTRODUCTION}

Polysora rust (also called Southern rust) is caused by Puccinia polysora Underwood and has enormous destructive potential on susceptible corn hosts. First identified in Alabama in 1891 on Tripsacum dactyloides L. (Underwood, 1897), the disease has become common in the warm tropics and subtropics. Severe epiphytotics occurred in West Africa in the decade following 1949 with yield losses up to 50\% (Rhind et al., 1952; Cammack, 1954; Robinson, 1996). Losses to this rust disease in America have also been up to 45\% (Raid et al., 1988; Rodriguez-Ardon et al., 1980), a severity attributed in part to the nearly uniform susceptibility of temperate hybrids (Futrell, 1975).

Common rust (caused by Puccinia sorghi Schw.) is found in tropical highlands and in temperate regions, and often occurs together with polysora rust in the winter in Hawaii. Disease symptoms and sources of resistance (Kim et al., 1980) are quite different, e.g., pustules of the two pathogens differ in color, size and shape (Ullstrup, 1977). Polysora rust is favored by high temperature and

${ }^{1}$ Grassland \& Forages Research Center, National Institute of Animal Science, Rural Development Administration, Cheonan, 330-800, South Korea

* Corresponding author (E-mail: yamakawa@agr.kyushu-u. ac.jp) high relative humidity (Shurtleff, 1980), and is considerably more devastating with the ability to kill plants (Scott et al., 1984).

Monogenic resistance has been identified to races of both common and polysora rust, but they have not proved of value in the tropics where racial variation of the pathogen appears to be widespread. Storey and Howland (1957) and Ullstrup (1965) identified several raciallyspecific resistance genes to polysora rust, but they were soon overcome by racial variation of the pathogen (Robinson, 1996). The resistance gene, $\operatorname{Rpp} 9$, confers tolerance to a common race in temperate regions. Nonracially specific or general resistance to polysora rust has been identified in field corn, and predominantly in tropical germplasm (Bailey et al., 1987; Zummo, 1988; Brewbaker et al., 1989).

A dozen sets of recombinant inbred lines (RIL) from crosses of temperate with tropical inbreds have been created in Hawaii (Moon, 1995). Polysora rust in the Philippines was studied in Set G, based on a cross of Thai inbred Ki14 (resistant) with Iowa inbred B68 (susceptible), and appeared to be governed by one major locus (Moon et al., 1999). Ming (1995) then identified RFLPs (restriction fragment length polymorphisms) linked to five quantitative trait loci (QTL) in this Set G. A major source of resistance was on chromosome 2 with minor genes on 4, 6, 9 and 10 . 
Holland et al. (1998) studied the inheritance of resistance to polysora rust in $\mathrm{F}_{2: 3}$ populations in North Carolina. Broad-sense heritability estimates from two populations were $30 \%$ and $50 \%$, respectively. A single locus on the short arm of chromosome 10 , in the region of monogene rpp9 was identified to contribute $82-83 \%$ of the variation in resistance. QTL on chromosomes 3, 4 and 10 and their epistatic interactions helped explain over $96 \%$ of the variation in the two populations.

The aim of this study was to determine the mode of inheritance and to estimate genetic parameters of polysora rust resistance and to know cell wall contents in progenies based on inbred Hi38 (resistant) in Hawaii.

\section{MATERIALS AND METHODS}

\section{Plant materials}

$\mathrm{F}_{1}, \mathrm{~F}_{2}, \mathrm{BC} 1$ and $\mathrm{BC}_{2}$ populations were derived by So (2003) from the parental inbreds Hi38-71 (resistant) and G24 (susceptible). The Hi38 designation includes a series of sister inbreds with a 60-generation pedigree of high polysora tolerance that are widely used in tropical supersweet corn breeding based on the gene brittle-1 (Brewbaker, 2003). Inbred Hi38-71 is a subline with unusual tolerance to corn leaf aphids (So, 2003). G24 is a recombinant field corn inbred from Set G described above, and derives its susceptibility from the temperate dent inbred B68 (Moon, 1995).

Field experiments were laid out as randomized complete block (RCB) designs with three replications at Waimanalo Research Station, University of Hawaii, Island of Oahu. A winter trial was planted in 2002 and a spring trial was planted in 2004. Corn trials are planted every month of the year at this station, permitting year-round survival of the rusts (Brewbaker, 2003). The trials were planted in $5 \mathrm{~m}$ rows with $0.75 \mathrm{~m}$ between-row spacing and about 25 plants per row. Plots consisted of two rows for parents and $F_{1}$, four rows for backcrosses and six rows for $\mathrm{F}_{2}$ populations. Parents were planted in adjacent plots to minimize competition from hybrids. Nurseries were planted with no pesticide application, facilitating epiphytotics. Two untreated seeds were planted per hill thinned to one per hill at a stand of 60,000 plants per hectare.

Additional 3-rep rust-tolerance trials were planted in 2003 and 2005 of Set M RILs, based on hybrids of supersweet inbreds Ia453sh2 (Iowa) and Hi38c1 (Hawaii), the latter a sister line of Hi38-71. Results of the 2003 trial were summarized by Ji and Brewbaker (2005).

\section{Measurement methods}

Field infections by polysora rust optimized between December and April when data were taken. In the generation mean analysis, evaluations were made of 60 plants of each parent, 60 plants of $\mathrm{F}_{1}, 180$ plants of $\mathrm{F}_{2}$ and 120 plants each of $\mathrm{BC}_{1}$ (Backcross 1 ) and $\mathrm{BC}_{2}$ (Backcross 2). Rust scores were taken about three weeks after silking on ten plants per row using the 9-class rating scale of Kim et al. (1980). In this scale, $1=$ highly resistant (less than $1 \%$ area on lower leaves infected); $2-3=$ resistant
(2-20\% area on lower leaves and ear-leaf covered by pustules); 4=moderately resistant (21-35\% area on lower leaves and ear-leaf covered by pustules); $5=$ intermediate (36-50\% area on lower leaves and ear-leaf covered by pustules, often ambiguous for classification into resistance); $6=$ moderately susceptible (51-65\% area on lower leaves, ear-leaf and upper leaves covered by pustules with some infection on leaf sheaths); 7-8=susceptible (66-80\% area on all leaves covered by pustules, with heavy infection on sheaths); $9=$ highly susceptible (more than $80 \%$ of the area on entire plant covered by pustules with premature death of plants).

Statistical analysis of generation means began with a three-parameter model that excluded non-allelic gene interactions. This model was tested by simple scaling tests followed by a joint scaling test. We used a digenic model involving the five parameters, $\mathrm{m}$, [a], [d], [aa] and [dd]. The data were analyzed by spreadsheet methods modified from Gamble (1962) and Mather and Jinks (1977). In these formulas, the parameters m, a, d, aa, ad and dd refer to effects of the mean, additive, dominance, additive $\times$ additive, additive $\times$ dominance, and dominance $x$ dominance, respectively. Narrow-sense heritability $\left(\mathrm{h}_{\mathrm{ns}}^{2}\right)$ was estimated following the method proposed by Warner (1952): $h_{n s}^{2}=\left[2 V_{\mathrm{F} 2}-\left(\mathrm{V}_{\mathrm{B} 1}+\mathrm{V}_{\mathrm{B} 2}\right)\right] / \mathrm{V}_{\mathrm{F} 2}$, where $\mathrm{V}_{\mathrm{F} 2}, \mathrm{~V}_{\mathrm{B} 1}$, and $\mathrm{V}_{\mathrm{B} 2}$ are the variances of the $\mathrm{F}_{2}, \mathrm{BC}_{1}$, and $\mathrm{BC}_{2}$ generations. Broad-sense heritability $\left(\mathrm{h}_{\mathrm{bs}}^{2}\right)$ was estimated as proposed by Burton (1951).

To know cell wall contents (\%) of the parental inbreds Hi38-71 (resistant) and G24 (susceptible), crude protein (CP) was determined by the method of AOAC method (1990) and acid detergent fiber (ADF) and neutral detergent fiber (NDF) of the parental inbreds Hi3871 (resistant) and G24 (susceptible) were determined by the method of Goering and Van Soest (1970).

\section{RESULTS AND DISCUSSION}

Polysora rust epiphytotics were severe each winter of the study, clearly distinguishing inbreds with different degrees of resistance. Mean scores of the combined data

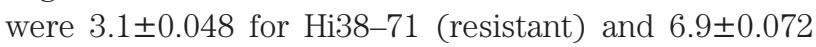
for G24 (susceptible) (Table 1).

The $F_{1}$ hybrids were very vigorous and showed a high level of rust resistance and high uniformity of

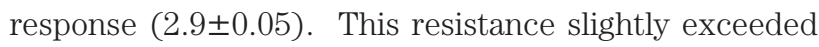
that of the resistant parent and appeared to be a function of heterosis of the hybrid. The $\mathrm{F}_{2}$ mean was intermediate to those of the parents, with wide variation around the mean (4.2 \pm 0.058$)$. Mean scores for backcrosses to resistant parent $(3.8 \pm 0.051)$ and to the susceptible parent $(5.8 \pm 0.069)$ were skewed toward the parental inbred mean, and both showed wide variations.

Individual scaling tests were applied to the data to test the possible involvement of non-allelic interactions (Table 2). All tests were significant, indicating the presence of non-allelic interactions. The joint scaling test for the 3-parameter additive-dominance model was also applied to data from winter and spring trials (Table 3 ). These results and those of the combined data (Table 4) 
Table 1. Estimates of mean, variance, number of plant, variance of mean and standard error of polysora rust rating for the Hi38-71 × G24 family (combined)

\begin{tabular}{|c|c|c|c|c|c|c|}
\hline Generations & Mean* & Variance & $\begin{array}{l}\text { C.V. } \\
\text { (\%) }\end{array}$ & $\begin{array}{c}\text { No. } \\
\text { of plant }\end{array}$ & $\begin{array}{l}\text { Variance } \\
\text { of mean }\end{array}$ & $\begin{array}{c}\text { Standard } \\
\text { error }\end{array}$ \\
\hline $\mathrm{P}_{1}$ & 3.1 & 0.28 & 16.7 & 120 & 0.0023 & 0.048 \\
\hline $\mathrm{P}_{2}$ & 6.9 & 0.63 & 11.5 & 120 & 0.0053 & 0.072 \\
\hline Mid-parent & 5.0 & & & & & \\
\hline $\mathrm{F}_{1}$ & 2.9 & 0.31 & 19.2 & 120 & 0.0026 & 0.050 \\
\hline $\mathrm{F}_{2}$ & 4.2 & 1.20 & 25.8 & 360 & 0.0033 & 0.058 \\
\hline $\mathrm{BC}_{1}$ & 3.8 & 0.63 & 20.6 & 240 & 0.0026 & 0.051 \\
\hline $\mathrm{BC}_{2}$ & 5.8 & 1.13 & 18.4 & 240 & 0.0047 & 0.069 \\
\hline
\end{tabular}

* Rating scale(1 9); 1= highly resistance, 9=highly susceptible

Table 2. Individual scaling tests on polysora rust resistance rating (1-9) between Hi38-71 and G24 parents

\begin{tabular}{cccc}
\hline Test & Winter & Spring & Combined \\
\hline $\mathrm{A}=2 \mathrm{BC}_{1}-\mathrm{P}_{1}-\mathrm{F}_{1}$ & $1.49 \pm 0.15^{* *}$ & $2.30 \pm 0.18^{* *}$ & $1.70 \pm 0.12^{* *}$ \\
$\mathrm{~B}=2 \mathrm{BC}_{2}-\mathrm{P}_{2}-\mathrm{F}_{1}$ & $1.57 \pm 0.18^{* *}$ & $2.28 \pm 0.24^{* *}$ & $1.79 \pm 0.16^{* *}$ \\
$\mathrm{C}=4 \mathrm{~F}_{2}-2 \mathrm{~F}_{1}-\mathrm{P}_{1}-\mathrm{P}_{2}$ & $0.82 \pm 0.32^{*}$ & $2.35 \pm 0.41^{* *}$ & $1.22 \pm 0.27^{* *}$ \\
\hline
\end{tabular}

*, **; $5 \%$ and $1 \%$ levels of significant, respectively.

Table 3. Joint scaling test of the additive-dominance (three parameter) model on the Hi38-71 × G24 family for polysora rust resistance rating from Winter and Spring trials

\begin{tabular}{|c|c|c|c|c|c|c|c|c|c|c|}
\hline \multirow{2}{*}{$\begin{array}{l}\text { Gener- } \\
\text { ation }\end{array}$} & \multirow{2}{*}{ Seasons } & \multirow{2}{*}{$\begin{array}{l}\text { No. of } \\
\text { Plant }\end{array}$} & \multirow{2}{*}{ Variance } & \multicolumn{3}{|c|}{ Model } & \multicolumn{2}{|c|}{ Mean } & \multirow{2}{*}{$\begin{array}{c}\text { Differ-ence } \\
\mathrm{O}-\mathrm{E}\end{array}$} & \multirow{2}{*}{$(\mathrm{O}-\mathrm{E})^{2} / \mathrm{E}$} \\
\hline & & & & $\mathrm{m}$ & $\mathrm{a}$ & $\mathrm{d}$ & $\mathrm{O}$ & $\mathrm{E}$ & & \\
\hline \multirow[t]{2}{*}{$\mathrm{P}_{1}$} & Winter & 60 & 0.17 & 1 & 1 & 0 & 3.2 & 3.4 & -0.18 & $<1$ \\
\hline & Spring & 60 & 0.27 & & & & 2.9 & 3.5 & -0.34 & $<1$ \\
\hline \multirow[t]{2}{*}{$\mathrm{P}_{2}$} & Winter & 60 & 0.37 & 1 & -1 & 0 & 6.9 & 7.1 & -0.25 & $<1$ \\
\hline & Spring & 60 & 0.62 & & & & 6.8 & 7.1 & -0.26 & $<1$ \\
\hline \multirow[t]{2}{*}{$\mathrm{F}_{1}$} & Winter & 60 & 0.19 & 1 & 0 & 1 & 2.9 & 3.2 & -0.33 & $<1$ \\
\hline & Spring & 60 & 0.30 & & & & 2.5 & 3.2 & -0.37 & $<1$ \\
\hline \multirow[t]{2}{*}{$\mathrm{F}_{2}$} & Winter & 180 & 0.92 & 1 & 0 & 0.5 & 4.2 & 4.2 & -0.07 & $<1$ \\
\hline & Spring & 180 & 1.19 & & & & 4.3 & 4.3 & -0.07 & $<1$ \\
\hline \multirow[t]{2}{*}{$\mathrm{BC}_{1}$} & Winter & 120 & 0.45 & 1 & 0.5 & 0.5 & 3.8 & 3.3 & 0.49 & $<1$ \\
\hline & Spring & 120 & 0.62 & & & & 3.9 & 3.4 & 0.44 & $<1$ \\
\hline \multirow[t]{2}{*}{$\mathrm{BC}_{2}$} & Winter & 120 & 0.70 & 1 & -0.5 & 0.5 & 5.7 & 5.2 & 0.50 & $<1$ \\
\hline & Spring & 120 & 1.12 & & & & 5.8 & 5.2 & 0.56 & $<1$ \\
\hline \multirow[t]{2}{*}{$\chi^{2}(3)$} & Winter & & & & & & $60.77 * *$ & & & \\
\hline & Spring & & & & & & $18.53 * *$ & & & \\
\hline
\end{tabular}

O: Observed, E: Expected, ** significant at 1\% level of probability.

also showed high significance. It was concluded that rust variations could not be explained by the three parameters alone, and the three epistatic interactions [aa], [ad] and $[\mathrm{dd}]$ were then included for analysis.

All six parameters were computed by the perfect-fit method proposed by Mather and Jinks (1977). The test revealed that all but the additive $\times$ dominance interaction were highly significant (Table 5). No test of the adequacy of the six-parameter model was possible because the number of estimated components was equal to that observed means, leaving no degree of freedom for the test of goodness of fit. Since there was no significant [ad] interaction, it was then omitted. This permitted a test of a five-parameter model with one degree of freedom and it also improved the precision with which the remaining parameters were estimated.

The joint scaling test for the five-parameter model produced a $\chi^{2}$ value of 0.76 , indicating no significant departure from expectation (Table 5). Moreover, all five parameters remained significant after fitting the fiveparameter model. Genetic variations could thus be explained fully by the five parameters, including the two types of epistatic interactions [aa] and [dd]. Trigenic interactions appeared not to make a significant contribution to the differences among the generation means. There was also a marginal improvement in the precision, 
Table 4. Joint scaling test of the additive-dominance (three parameter) model on the Hi38-71 $\times$ G24 family for polysora rust resistance rating from combined data

\begin{tabular}{ccccccccc}
\hline \multirow{2}{*}{ Generation } & Variance & \multicolumn{3}{c}{ Model } & \multicolumn{3}{c}{ Mean } & Differ-ence \\
\cline { 3 - 7 } & & $\mathrm{m}$ & $\mathrm{a}$ & $\mathrm{d}$ & $\mathrm{O}$ & $\mathrm{E}$ & $\mathrm{O}-\mathrm{E}$ & $(\mathrm{O}-\mathrm{E})^{2} / \mathrm{E}$ \\
\hline $\mathrm{P}_{1}$ & 0.28 & 1 & 1 & 0 & 3.1 & 3.3 & -0.23 & $<1$ \\
$\mathrm{P}_{2}$ & 0.63 & 1 & -1 & 0 & 6.9 & 7.2 & -0.29 & $<1$ \\
$\mathrm{~F}_{1}$ & 0.31 & 1 & 0 & 1 & 2.8 & 3.3 & -0.39 & $<1$ \\
$\mathrm{~F}_{2}$ & 1.20 & 1 & 0 & 0.5 & 4.2 & 4.3 & -0.03 & $<1$ \\
$\mathrm{BC}_{1}$ & 0.63 & 1 & 0.5 & 0.5 & 3.8 & 3.3 & 0.54 & $<1$ \\
$\mathrm{BC}_{2}$ & 1.13 & 1 & -0.5 & 0.5 & 5.8 & 5.2 & 0.55 & $<1$ \\
\hline$\chi^{2}(3)$ & & & & & $76.27 * *$ & & &
\end{tabular}

O: Observed, E: Expected, ** significant at 1\% level of probability.

Table 5. Estimates of the components of the generation means for the cross Hi38-71 × G24 fitting a six parameter model by perfect fit estimation and a five parameter model by the weighted least square

\begin{tabular}{ccc}
\hline Generation & Six parameter & Five parameter \\
\hline $\mathrm{m}$ & $2.71 \pm 0.29 * *$ & $2.73 \pm 0.29 * *$ \\
{$[\mathrm{a}]$} & $-1.88 \pm 0.04 * *$ & $-1.89 \pm 0.04 * *$ \\
{$[\mathrm{~d}]$} & $5.94 \pm 0.71 * *$ & $5.87 \pm 0.69 * *$ \\
{$[\mathrm{aa}]$} & $2.27 \pm 0.29 * *$ & $2.25 \pm 0.28 * *$ \\
{$[\mathrm{ad}]$} & $-0.19 \pm 0.19 \mathrm{~ns}$ & - \\
{$[\mathrm{dd}]$} & $-5.77 \pm 0.44 * *$ & $-5.72 \pm 0.42 * *$ \\
\hline$\chi^{2}(1)$ & - & $0.766^{\mathrm{ns}}$ \\
\hline
\end{tabular}

*, ** ; Significant at $5 \%$ and $1 \%$ levels, respectively and ns means not significant.

Table 6. Expected generation means based on three and five parameter models

\begin{tabular}{|c|c|c|c|}
\hline \multirow{2}{*}{ Generation } & \multirow{2}{*}{$\begin{array}{l}\text { Observed } \\
\text { Mean }\end{array}$} & \multicolumn{2}{|c|}{ Expected mean } \\
\hline & & Three parameter & Five parameter \\
\hline $\mathrm{P}_{1}$ & 3.10 & 3.33 & 3.09 \\
\hline $\mathrm{P}_{2}$ & 6.86 & 7.16 & 6.87 \\
\hline $\mathrm{F}_{1}$ & 2.88 & 3.28 & 2.88 \\
\hline $\mathrm{F}_{2}$ & 4.24 & 4.26 & 4.24 \\
\hline $\mathrm{BC}_{1}$ & 3.84 & 3.31 & 3.86 \\
\hline $\mathrm{BC}_{2}$ & 5.77 & 5.22 & 5.74 \\
\hline$\chi^{2 \dagger}$ & - & $76.27 * *$ & $0.22^{\mathrm{ns}}$ \\
\hline
\end{tabular}

reflected in slightly lower standard errors.

Expected generation means based on the three- and five-parameter models are presented in Table 6. The three-parameter model produced expected means that differed significantly from observed means $\left(\chi^{2}=76.27^{* *}\right)$. In contrast, expected means on the five-parameter model were essentially identical to observed means $\left(\chi^{2}=0.22\right)$. Broad-sense heritability of polysora rust ratings on a family basis averaged $68.31 \%$ and narrow-sense heritability averaged 53.31\%. The minimum number of effec-
Table 7. Cell wall contents (\%) of corn leaf of the parental inbreds Hi38-71 (resistant) and G24 (susceptible)

\begin{tabular}{ccccc}
\hline Varieties & CP & ADF & NDF & IVDMD \\
\hline Hi38-71 & 8.18 & 43.11 & 69.61 & 54.43 \\
G24 & 10.43 & 34.70 & 65.00 & 42.76 \\
\hline
\end{tabular}

$\mathrm{CP}$ : Crude protein, ADF : Acid detergent fiber, NDF : neutral detergent fiber, IVDMD : in vitro dry matter digestibility

tive gene loci, based on Castle and Wright formulas, was 1.99. It is concluded that resistance to Puccinia polysora rust in this population is controlled by at least two major loci acting with a high degree of dominance and epistasis.

Set M of RILs was studied for rust tolerance during this period, and the results published by Ji and Brewbaker (2006). The parent inbreds were Hi38c1, a sister line of

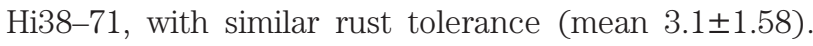
The susceptible parent was a well-known sweet corn from

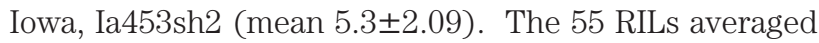
4.5 and ranged from 2.0 to 7.0 (Ji and Brewbaker, 2006). Few inbreds were as resistant as the Hi38 parent. An additional set of rust evaluations of Set $\mathrm{M}$ was made in the winter of 2005 by Brewbaker (unpublished). This trial was planted in November 2005 and suffered a severe epiphytotic from which only eight inbreds were classi-

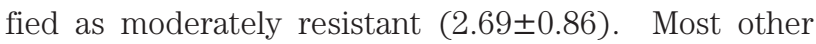
inbreds were killed by the disease. In the same nursery many temperate sweet corn hybrids failed to set seed due to the rust. Many of the Set M inbreds are ill-adapted to the short days and high stresses of the tropics, and their lack of vigor clearly contributed to their low rust tolerance. The data argue for at least two segregating QTL required for resistance in this set of RILs.

CP of Hi 27 was higher as $10.43 \%$ than that of Hi3871 but $\mathrm{ADF}$ and NDF of Hi27 were lower as $34.70 \%$ and $65 \%$ than those of Hi38-71 (Table 7).

\section{DISCUSSION}

The two genetic studies of resistance to polysora rust (Puccinia polysora Underwood) conferred by tropical sweet corn inbred Hi38 confirm a minimum of two con- 
trolling QTL. Inbreds such as Hi38 show many lesions on lower leaves, while leaves above the ear are often quite clean of rust. This condition has been described as "mature-plant resistance" or "late-rusting" (Bailey et al., 1987). We conclude that resistance of the Hi38 type is adequate for sweet corn production under typical epiphytotics in Hawaii, and that resistance genes have a relative high dominance useful for genetic conversions.

Statistically, a digenic model adequately explained the observed genetic variations. However, epistasis of both the additive $\times$ additive and dominance $\times$ dominance types were significant. Higher order interactions such as trigenic epistasis did not appear to contribute to variations among the generations studied. The involvement of epistatic interactions for polysora rust resistance in Tropical Corn Belt corn population was also reported by Holland et al. (1998). Bias is expected in estimating additive and dominance effects when epistasis is significant (Hallauer and Miranda, 1981).

Information was not gained on gene effects in different genetic backgrounds or environments in this study. However, related inbreds in the Hawaii supersweet breeding program have levels of resistance comparable to that of Hi38 (Brewbaker, 2003), and occur in most commercial hybrids grown year-round in Hawaii. The results of this study provide direction for the breeding of polysora rust resistance corn varieties. A negative sign for [dd] implies interactions between increasing and decreasing alleles, suggesting some level of dispersion in Hi38 and indicating that further improvement of resistance is possible. Significance of [a] and [aa] also implies that part of resistance can be fixed in inbred lines of corn. Due to simultaneous significance of [d] and [dd], a reciprocal recurrent selection scheme seems appropriate. The Hi38-71 inbred may be of particular value in sweet corn breeding for tropical regions due to its dual resistance to corn leaf aphid and polysora rust (So, 2003).

Resistance of polysora rust is more important in field corn than in sweet corn, due to the impact of disease on grain filling. Brewbaker et al. (1989) tested more than 150 field corn inbreds world-wide, including five evaluations of polysora resistance. Many tropical flint inbreds showed very high levels of resistance. Twenty seven of these have been released following their conversion (six backcrosses) for resistance to maize mosaic virus resistance (Brewbaker, 2006). Among these were inbreds Hi44 and Hi55 from Set G (with resistance from the Thai parent, Ki14) that were much more resistant than sweet corns of the Hi38 type.

Field epiphytotics in Hawaii's winter months were adequate for present studies, but breeding would be facilitated by using artificial inoculations and susceptible spreader rows in the field. Mapping of polysora rust QTL with molecular markers could help breeders in markerassisted selection, if costs are controllable. Digital estimates of lesion areas on a major leaf would perhaps distinguish genotypes more clearly. Our studies demonstrate that rust evaluation of poorly adapted inbreds is probably unwise, and that evaluation of testcrosses might lead to more convincing classification.

\section{ACKNOWLEDGMENTS}

The authors acknowledge the support of research station staff of the University of Hawaii in conduct of these field experiments, and the counsel of Prof. James L. Brewbaker in analysis and presentation of the data. Financial support came from T/STAR grant EMIS 657921 to Dr. Brewbaker from the U. S. Dept. Agriculture.

\section{REFERENCES}

AOAC 1990 Official methods of analysis (15 ${ }^{\text {th }}$ ed.). Association \& Official Analysis Chemists, Washington DC

Bailey, B. A, W. Schuh, R. A. Frederiksen and A. J. Bockholt 1987 Identification of slow-rusting resistance to Puccinia polysora in maize inbreds and single crosses. Plant Disease, $\mathbf{7 1}$ : $518-521$

Brewbaker, J. L. 2003 Corn production in the tropics: The Hawaii experience. College of Tropical Agric. Human Resources Research Ser. pp. 52-53

Brewbaker, J. L, M. L. Logrono and S. K. Kim 1989 The MIR (Maize Inbred Resistance) trials: Performance of tropicaladapted maize inbreds. Hawaii Inst. Trop. Agric. Human Resources Research Ser., 62: pp. 27

Burton, W. G. 1951 Quantitative inheritance in pearl millet (Pennisetum glaucum). Agron. J., 43: 409-417

Cammack, R. H. 1954 Observation in Puccinia polysora Underwood in West Africa. West Africa Maize Rust Res. Unit Annu. Rep. 1 (1953): 16-31

Futrell, M. C. 1975 Puccinia polysora epidemics on maize associated with cropping practice and genetic homogeneity. Phytopathology, 65: 1040-1042

Gamble, E. E. 1962 Gene effects in corn (Zea mays L.) I. Separation and relative importance of gene effects for yield. Can. J. Plant Sci., 42: 339-348

Goering, H. K., and Van Soest, P. J. 1970 Forage fiber analysis (apparatus, reagents, procedures and some applications). In: Agriculture Handbook No. 379. Agriculture Research Service, United States Department of Agriculture, Washington, USA

Hallauer, A. R., and J. B. Miranda FO 1981 Quantitative genetics in maize breeding. Iowa State University Press. Ames, Iowa

Holland, J. B., D. V. Uhr, D. Jeffers and M. M. Goodman 1998 Inheritance of resistance to southern corn rust in tropicalby-corn-belt maize populations. Theor. Appl. Genet., 96: $232-241$

Ji, H. C. and J. L. Brewbaker 2006 Segregation of resistance to southern corn rust in set M RIL population. Maize Newsletter, 80: 11-12

Kim, S. K., I. W. Buddenhagen and J. L. Brewbaker 1980 Changes in the apparent resistance of maize to Puccinia sorghi Schw. during development. SABRAO J., 12: 139-147

Mather, K. and J. L. Jinks 1977 Introduction to biometrical genetics. Chapman and Hall Ltd., London

Ming, R. G. 1995 Restriction fragment length polymorphism analysis of host-plant resistance to four maize pathogens. Ph.D. thesis. University of Hawaii

Moon, H. G. 1995 Quantitative genetic analysis of recombinant inbred lines (RILs) from tropical maize single crosses. Ph.D. thesis. University of Hawaii

Moon H. G., J. L. Brewbaker and X. W. Lu 1999 Major QTLs for disease resistance and other traits identified in recombinant inbred lines from tropical maize hybrids. Maydica, 44: 301311

Raid, R. N., S. P. Pennypacker and R. E. Stevernson 1988 Characterization of Puccinia polysora epidemics in Pennsylvania and Maryland. Phytopathology, 78: 579-585

Rhind, D., J. M. Waterston and F. C. Deighton 1952 Occurrence of Puccinia polysora Underw. in West Africa. Nature, 169: 
631

Robinson, R. A. 1996 Maize in tropical Africa. In Return to Resistance; Breeding crops to reduce pesticide dependence. AgAccess, Davis, CA., pp. 173-199

Rodriguez-Ardon, R., G. E. Scott and S. B. King 1980 Maize yield losses caused by southern corn rust. Crop Sci., 20 812-814

Ryland, A. K., and H. H. Storey 1955 Physiological races of Puccinia polysora Underw. Nature, 176: 655-656

Scott, G. E., S. B. King and J. W. Armour, JR. 1984 Inheritance of resistance to southern corn rust in maize populations. Crop Sci., 24: 265-267

So, Y-S. 2003 Corn leaf aphid and polysora rust resistance in tropical maize. MS thesis, Dept. Horticulture, Univ. Hawaii. p. 86
Storey, H. H., and A. K. Howland 1957 Resistance in maize to the tropical American rust fungus, Puccinia polysora Underw. I. Genes $R p p_{1}$ and $R p p_{2}$. Heredity, 11: 289-301

Ullstrup, A. J. 1965 Inheritance and linkage of a gene determining resistance in maize American race of Puccinia polysora. Phytopathology, 55: 425-430

Ullstrup, A. J. 1977 Diseases of corn. In corn and corn improvement. American Society of Agronomy, Inc., Madison, Wisconsin

Underwood, L. M. 1897 Some new fungi chiefly from Alabama Bull. Torrey Bot. Club, 24: 81-86

Zummo, N. 1988 Components contributing to partial resistance in maize to Puccinia polysora. Plant Disease, 72: 157-160

Warner J. N. 1952 A method for estimating heritability. Agron. J., 44: 427-430 